\title{
Employment of Foreigners from Bosnia and Herzegovina and Serbia in Slovenia
}

\author{
KATJUŠA KOSTANJŠE K \\ International School for Social and Business Studies, Slovenia \\ kostanjsek.kaja@gmail.com \\ GREGOR JAGODIČ \\ International School for Social and Business Studies, Slovenia \\ gregor.jagodic@mfdps.si
}

\begin{abstract}
Due to the lack of specific professions in the Slovenian labour market, more and more Slovenian employers are employing foreigners from Bosnia and Herzegovina $(\mathrm{BiH})$ and Serbia. Our research has found that employers when recruiting most often encounter a lack of adequate candidates in the market and complex administrative procedures for the employment of foreigners coming from $\mathrm{BiH}$ and Serbia. Because of the easier and faster integration of foreigners into the work environment, companies provide various types of assistance, but often face the unwillingness of foreigners to adapt to the new environment. In the framework of the verification of the hypotheses and the conclusion of the article, we give the companies proposals to facilitate the employment procedures of foreigners and their faster integration into the work and living environment.
\end{abstract}

Key words: labour market, foreign workers, employment practices, Bosnia and Herzegovina, Serbia, employee integration

(c) BY-SA https://doi.org/10.26493/1854-4231.15.265-289

\section{Introduction}

The lack of certain profiles has been present on the Slovenian labour market for a long time. Therefore, Slovenian companies are sometimes forced to seek outside their own borders. It is interesting to note that in Slovenia at the end of year 2018, there were about 33,000 more foreigners than in 2015 (Raičevič 2019). Free movement of goods, capital, services and persons applies for Slovenia, as a member of the European Union (EU). And free movement allows citizens of the Member States of the European Union and their family members to move freely - with a purpose to work, study, retire and live between Member States. As a result, many administrative obstacles have been reduced. While the Republic 
of Slovenia has an established right to free movement of workers with all Member States, the Republic of Croatia remains the exception. Workers who are citizens of the Republic of Croatia need a work permit to work in our country. This is not necessary for other Member States and countries of the European Economic Area (Norway, Iceland, Liechtenstein) and the Swiss Confederation, since citizens and their immediate family members in our labour market are completely equivalent to Slovenian citizens (free to self-employment or to work without work permits) (see http: //www.mddsz.gov.si/si/delovna_podrocja/trg_dela_in_zaposlovanje/ delovne_migracije/prost_pretok).

The situation is different for foreigners coming from third countries. Their employment in our country is carried out in accordance with the provisions of the Employment, Self-Employment and Work of Foreigners Act, which came into force on September 1, 2015.

\section{Current Situation on the Slovenian Labour Market}

The Employment Service of Slovenia (zRsz) regularly publishes forecasts of the Occupational Barometer, which forecast labour market deficits. The forecast includes jobs that are expected to balance supply and demand, and those that are expected to have fewer job vacancies than actual job seekers.

According to various surveys from 2018, including the Occupational Barometer of zRsz (Kušar 2018), a 'list' of occupations has been compiled, which for 2019 also predicted that demand will be much higher than actual supply or that there will be further severe lack of adequate candidates in the labour market. In these occupations we include: cleaners, simple workers, electrical and electromechanical engineers, electrical technicians, mechanical engineers, chemists, mechanics and repairers, carpenters, waiters, cooks, salesmen, machine operators, drivers, masons, tool makers, pharmacists, specialist doctors, etc.

According to the Occupational Barometer of zRsz, the excess of providers in the labour market is mainly reflected in the following professions: business secretary, journalist, economist, graphic designer, store manager, educator, official in finance and insurance, translator, etc. (Zavod Republike Slovenije za zaposlovanje 2018).

\section{Foreign Countries and Employment Areas in 2018}

According to the data of the Health Insurance Institute, from December 31, 2018, there were 74,028 foreigners employed in Slovenia. Most of them are from the republics of the former Yugoslavia: 43,512 
from $\mathrm{BiH}$, 11,010 from Serbia, 7,026 from Croatia, 6,495 from Kosovo, 5,582 from North Macedonia and 403 from Montenegro (Raičevič 2019).

The rest of the foreigners are from different countries and as of 31 December 2018 they were employed in Slovenia: 2,635 from Bulgaria, 1,268 from Italy, 1,417 from Russia and 1,107 from Ukraine. These are countries that employ more than 1,00o people. Fewer than 1,00o people were in 2018 employed from: Hungary 592, China 575, Romania 543, Slovakia 297, Germany 154, Turkey 133, France 130, Thailand 129, India 118, United Kingdom 121, Moldova 110 and the United States 86 (Raičevič 2019).

According to the statistics from November, in 2018 the majority of foreigners in Slovenia were employed in construction jobs (around 21,000 ). This was followed by employment in manufacturing (nearly 17,000 ), transport and storage (around 13,500) and just under 4,000 foreigners in the hospitality industry. 2,200 people were employed in various technical, professional and scientific activities and around 1,000 were employed in social care and health (Raičevič 2019).

The drastic lack of certain professions in the Slovenian labour market is one of the main reasons why employers decide to hire a foreigner. Another reason is the lack of technical knowledge, skills and experience of the candidates. All of this is also about the unwillingness of Slovenian workers to perform jobs that have been stigmatized by society to be of less value.

\section{Methods of Finding Foreign Personnel and Participants in the Search Process}

There are several ways of finding foreign personnel (Pušnik 2015):

- by social networks,

- through a network of HR professionals,

- by different HR agencies and

- by recruitment companies to find foreign personnel.

In the last year, recruitment agencies and foreign recruitment companies have decided to search for personnel by so called job fairs in the country from which they want to recruit a foreign. Employment events in $\mathrm{BiH}$ and Serbia are on the rise. Namely, these countries are said to have many workers with occupational profiles, which are drastically lacking in Slovenia and receive here a substantially higher salaries for the same work. That is why we are interested in them and the attendance at such events is numerous. Job 
fairs have the following advantages over other forms of personnel search:

- You can have more interviews at the booth than you would otherwise (for a large number of foreigners from $\mathrm{BiH}$ and Serbia is too expensive to travel to Slovenia and they can't afford it).

- You meet the candidates personally and make personal contact with them. Also, a foreigner can get first-hand information about a company looking for workers.

- Candidates can have interview immediately without applying for it and waiting for an invitation for the interview or without waiting for a response.

\section{Employment Process for a Foreign from Bosnia and Herzegovina and Serbia}

In the process of hiring a foreigner, it is crucial from which country he comes from, since the recruitment procedures vary considerably from country to country. As mentioned in the introduction, for citizens of the members of the European Economic Area (EEA) applies free movement of labour, while for third-country citizens it does not. In the following, we will focus only on the countries: $\mathrm{BiH}$ and Serbia.

\section{Documentation in the Employment Process for a Foreigner}

It is common for all foreigners that when the employer decides to hire him/her, he must provide all the necessary documentation that the employer will need in the process of obtaining a work permit or a single residence permit and work for the foreigner.

Documentation that foreigner must submit/provide to the employer (see http://evem.gov.si/evem):

- personal photo (as for the passport),

- certified copy of the passport,

- certified copy of driving license (when hiring a truck driver for example),

- certified copy of the certificate of completion of education or diploma,

- certificate of work experience (if required by PDM-KTD form; Job vacancy notice - labour market surveillance),

- a signed foreign authorization (in case the foreign procedure is regulated by the employer or intermediary),

- original certificate from the criminal record of impunity, 
- proof of commercial health insurance (sometimes arranged and obtained by the employer at his own expense) and

- certificate that he or she was registered at their Employment Service (until 2019 applied only to BiH citizens, now applies also to Serbian citizens - the latter also apply that a Slovenian employer can employ them even if they do not meet the unemployment conditions, but it is about the professional employment of an individual).

The employer must also prepare part of the documentation for the employment of the foreigner. As stipulated by the Employment, Self-Employment and Work of Foreigns Act (Zakon o zaposlovanju, samozaposlovanju in delu tujcev (ZZSDT-UPB2) 2018), during the procedure the latter must arrange for the preparation or signature:

- employment contracts with the right foreigner information, salary, job and duration of employment,

- statements that, as an employer, he or she provides accommodation for a foreigner,

- employer authorization (in case the employer procedure is regulated by an intermediary),

- statements and evidence that, as an employer, he or she has invested at least EUR 50,000 in the activity in which the foreigner is going to work before applying for a single permit for the employment of a foreigner (applies only to employers who are registered for less than six months).

\section{Steps in the Employment Process for a Foreigner}

The Employment, Self-Employment and Work of Foreigns Act clearly sets out all rules on the employment, self-employment and work of foreigners. The employment process of foreigners between the two countries ( $\mathrm{BiH}$ and Serbia) differ slightly; for citizens of the Republic of Serbia the process is shorter and consequently faster (from September 2019, we have an Agreement between the Government of the Republic of Slovenia and the Government of the Republic of Serbia about the employment of citizens of the Republic of Serbia in the Republic of Slovenia). While Serbian citizens can enter our country and stay, employ and work obtain only a single permit for residence and work, $\mathrm{BiH}$ citizens must obtain a work permit beforehand. For the latter conditions of employment and procedures for issuing work permits stipulates the Agreement between the Government of the Republic of Slovenia and the Council 
of Ministers of $\mathrm{BiH}$ on the employment of $\mathrm{BiH}$ citizens in the $\mathrm{Re}$ public of Slovenia from 2013. It is important to note that the process of obtaining a work permit will almost certainly be successful and quickly resolved if a foreigner will be employed in a job that requires deficient occupations. According to zRsz (see https://www.ess.gov .si/delodajalci/zaposlovanje_in_delo_tujcev/kontrola-trga-dela) deficient occupations continue to be: welders, heavy truck and tractor drivers, toolmaker, turner, electrician, bricklayer, carpenter, chef, electromechanic, sales specialist for Iст products and services, developer and software and applications analyst, and expert on databases and computer networks.

We present the more detailed steps in the process of hiring a foreigner from $\mathrm{BiH}$ or Serbia below.

Step 1: The PDM-KTD or the Job vacancy notice - labour market surveillance should be published on the zRsz. Labour market surveillance is compulsory for the employment of a foreigner from third countries. In doing so, the zRsz verifies the fulfilment of the requirement in the foreigner's recruitment process that there are no suitable persons or candidates for employment in the Slovenian unemployment register.

Step 2: Within five working days of receipt of the PDM-KTD form, the zRSz issues a notice if there are any unemployed persons in their records who would fit our call. If there are no suitable persons, as an employer we continue the process for employment of a foreigner (obtaining a work permit or a single permit for residence and work). The application for authorization must be submitted no later than 30 days after the issuance of the zRsz notification. If the zRSz finds suitable persons in the Slovenian unemployment register, employment of a foreigner is not possible. In such case, candidates can only be sought on the Slovenian labour market (see https://www.ess.gov .si/delodajalci/zaposlovanje_in_delo_tujcev/kontrola-trga-dela).

Step 3: Obtaining a work permit is the next step for $\mathrm{BiH}$ citizens. Based on this document, the employer can conclude an employment contract (Grofelnik and Premk 2009, 263). The application is submitted by the employer to the ZRSZ on the form TUJ-BIH-1. A foreigner who wants to get a job must be registered with the Employment Service of $\mathrm{BiH}$ for at least one day (see https://www.ess.gov.si/tujci/delo_ v_sloveniji/zaposlovanje-drzavljanov-bih).

Following the application, the Bosnian Employment Service requires from the employer:

- a signed contract of employment by the employer,

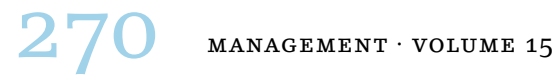


- a certified copy of the foreigner's passport,

- a certified copy of the certificate or diploma and

- a telephone number of the foreigner.

All documents can be submitted by the employer in PDF format by an e-mail, but only after they have received a request from the $\mathrm{BiH}$ Employment Service.

If all the documents are in accordance with the regulations and the Employment Service of $\mathrm{BiH}$ issues the consent for employment of their citizen with us, the Slovenian zRsz issues a work permit, which is always issued for a period of 3 years. In this case, the foreigner must be employed by the employer who obtained his work permit for the first 12 months, or by his legal successor. During the remaining 24 months of the validity of the permit, any other employer can employ the foreigner, since during this period he is free to enter the Slovenian labour market. After the validity of the work permit, this may be renewed under the terms of the Agreement (see https://www.ess.gov.si/tujci/delo_v_sloveniji/zaposlovanje-drzavljanovbih).

During this time or step, the foreigner should be referred to his/her nearest Slovenian embassy where he/she submits his/her fingerprints. This is a later requirement for the issue of a single residence and work permit.

Step 4: The next step is to obtain a single residence and work permit. We already submitted the application for the citizens of Serbia in Step 2, since in 2015 the procedure was simplified and the single permit merges and replaces the previous residence permit and work permit. For $\mathrm{BiH}$ citizens, this is only regulated after obtaining a work permit.

The application for mentioned permit should be submitted to the competent administrative unit. The single permit for residence and work (ED) is issued in the form of a card and is so called decision issued by the administrative unit in agreement with the zrsz (see https://www.ess.gov.si/delodajalci/zaposlovanje_in_delo_tujcev/vrste _soglasij_in_pogoji). The application must be accompanied by the following documents:

- a certified copy of the passport,

- a certificate from the criminal record of impunity (not to be older than three months),

- employment contract signed by both parties (employer and foreigner), 
- proof of commercial health insurance (concluded for at least one month),

- a certified copy of the certificate or diploma and

- any other evidence of compliance with the conditions laid down for the issue of the type of authorization concerned.

In case that any document is written in Cyrillic, a certified translation in the Slovenian language must be submitted (Upravna enota Ribnica 2017).

An ED is subject to the payment of a fee and the cost of issuing an ID. A taxpayer whose ED is issued on the basis of a work permit previously issued under an international agreement is exempt from the fee and pays only the application fee (Upravna enota Ribnica 2017).

Issuing an ED generally takes up to 15 days. Once the permit has been issued, the administrative unit, upon agreement with the employer, sends it to the embassy, where the foreigner has already submitted his fingerprints at the beginning of the employment process. When the embassy receives the ED, it informs the foreigner that the document is ready for pickup. He has 7 days for the ED to take over. The employer then has exactly 15 days to hire him from the day the foreigner picked up ED at the embassy. This means that on the 15th day after the pickup, a foreigner must already be in Slovenia and spend his first working day at work.

Step 5: Once we have obtained an ED for a foreigner and have been taken over by the Embassy, the employee's arrival process is initiated. This means that the employer and the foreigner agree on which will be his or her first working day so that he or she can organize his/her arrival in Slovenia in time.

During the procedure, the employer must also provide (if he wishes) accommodation for the worker. There are two options: either he has available accommodation (most often a room in a multifamily house or larger apartment), or finds suitable accommodation for a foreigner. It happens, however, that foreigners in Slovenia have relatives or friends and organize accommodation themselves.

Step 6: When a foreigner arrives in Slovenia, he reports to the employer on the day as agreed. Before the start of his/her first workday, a foreigner must settle several matters, namely:

- have a preliminary medical examination (organized by the employer),

- take an occupational safety exam (organized by the employer),

- declare temporary residence (at the Administrative Unit), 
- obtain a Slovenian tax code (at the Financial Administration),

- open a personal transaction account at the bank (at the selected bank) and

- arrange additional insurance (at the selected insurance company).

Upon arrival in Slovenia, the foreigner signs an employment contract with the employer again, which must, in substance, be the same as the one they signed at the beginning of the foreigner's employment process. The difference is that the new contract will specify the duration of the employment. Once the contract has been signed and the foreigner has settled all of the matters listed above, he may start to work from the next day.

Step 7: Once the employer has settled all matters related to the pre-employment process, he may also carry out the latter by registering a foreigner with compulsory health and pension insurance (Form M-1).

\section{Obstacles and/or Difficulties During and After the Employment of the Foreigner}

The process of hiring a foreigner has been simplified administratively in recent years. It is much easier for nationals of the members of the European Economic Area and Swiss nationals than for foreign nationals coming from third countries. Nonetheless, many employers face various difficulties during or after the employment process of a foreigner.

Many employers face problems early on. Namely, if one does not sufficiently inquire about all the details of the process itself, and what to look out for, it can quickly lead to complications that sometimes even lead to the termination of the foreigner's employment. Insufficient information and unfamiliarity with the process also leads to insufficient and unregulated necessary documentation. It is therefore of the utmost importance that the person conducting the process of hiring a foreigner is aware of the process, from an administrative, time, and legal point of view. If this is not possible, it is best for the company to use an external business partner (for example staffing agency) that has qualified employees for the process.

Another obstacle we can face right from the start is that we are dealing with the employment of a foreigner who is unresponsive, disobedient, incorrect ... We know that the candidate must provide more documents and certificates, which are the basis, that the employer can initiate the employment process. If it fails to do so, the 
timeframe is extended. This causes a great deal of dissatisfaction with most employers, as everyone wants to complete the process as soon as possible and the foreigner starts to work.

An obstacle that we face regularly in practice and cannot be influenced by is the responsiveness of the institutions. Although all institutions and offices have statutory deadlines for issuing certificates, permits, consents, and the like, responsiveness is contingent on the amount of applications pending.

Even when the employment process is completed and the foreigner joins us in the work environment, we as an employer may face obstacles or difficulties. The first problem is certainly the foreigner's lack of knowledge of the Slovenian language, which causes communication barriers. How important this problem is depends on the job. Many Slovenes, due to the former common state and the great similarity between the languages, thankfully, do speak or understand (or both) Croatian, Serbian or Bosnian, which makes it easier for the foreigner (and the employer) to communicate with each other.

Another problem that employers repeatedly encounter is that a foreigner finds it difficult or impossible to manage their life in a new environment. The fact is that our social and work culture is almost certainly different from the country our foreigner comes from. And if he/she does not find a company close to him/her (by tradition, customs, rules, etc.), he/she feels lost. Therefore, it is important for the employer to help him/her join the workforce, so that the foreigner can get to know the new environment as quickly as possible through co-workers and thus make new acquaintances that will help him/her. Often, citizens of the former Yugoslav Republics have no interest in joining Slovenian society. The reason is probably that there are so many of their fellow countrymen in Slovenia that they do not see any greater sense or need in adapting to the new environment.

A big problem in companies is discrimination against foreigners. This is especially true for citizens of the former Yugoslav Republics and southern countries (Bulgaria, Albania, Romania, etc.). For no good reason, foreigners are treated worse by associates (including leaders) simply because they are of another race, ethical background, religious belief, and the like. It is often the case that foreigners tell the superiors, but they do not act. In such cases, the work environment forces the foreigner to either subordinate or go to another employer or back to his/her country if the work permit does not allow him/her to do so.

Discrimination is also closely linked to harassment in the workplace. Although the Employment Relationships Act (Zakon o de-

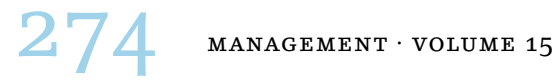


lovnih razmerjih (ZDR-1) 2013) clearly defines what an employer is obliged to do, what kind of work environment it must provide and what measures it must take to protect workers, this is often not the case. The citizens of $\mathrm{BiH}$, Serbia and other southern countries are also often the most affected.

Here are some key factors that we can use to predict an individual's performance abroad (Jerala, Podgoršek, and Toš 2016, 11-5):

- openness (curiosity, originality, intelligence - interest in learning new things, ready for new experiences),

- emotional stability (allows them to be more positive and confident, easier to handle problems),

- conscientiousness (organization, consistent performance of tasks, work performance),

- self-efficacy (the individual's ideas about his own abilities, high motivation),

- cultural sensitivity (adaptation to another environment and culture),

- previous experience (very welcome),

- family status (affects his well-being, work, and work motivation),

- social support (social network) and

- organisational support (information, emotional support, assistance with finances, family).

\section{Onboarding and Integration of a Foreigner into the Collective}

It is very important how the employer will arrange the foreigner's onboarding and integration into his collective in order to minimize the problems. In Slovenia, the term 'onboarding' is used more and more frequently to integrate a new employee into the company.

Onboarding is a carefully planned process of integrating a newly hired person, or associate we have transferred into the work environment. In integration, it is crucial that the newly recruited employee, especially the foreigner, feels welcome, accepted and part of the organization. The goal of such planned integration for the employer is to help the new employee to adapt to the new job easier and faster in both social and performance aspects (Ferk and Boštjančič 2015, 5).

Suggs (in Ferk and Boštjančič 2015, 7) says that onboarding must be designed to benefit both the individual and the employer. He also 
mentions that a new employee needs to have a very good understanding of their employer's vision and goals. At the same time, he or she must be familiar with the resources to which employee can turn when he or she wants or needs to draw on the knowledge that is in the organization and important information to work with. Of course, it is the job of the employer to provide the new employee with everything they need and will need in introducing and mastering their job. And when it comes to being a foreigner, it is highly recommended that the content, and more, is prepared in a language that the person understands. Only in this way can we avoid unnecessary inconvenience due to language barriers.

The main benefits of systematic foreigner integration are (see https://www.smartsheet.com/employee-onboarding-processes-plansbest-practices-flowcharts):

- a sense of acceptance and a sense of being part of an organization,

- a clear picture of what is expected of him/her at work,

- he/she will be better and faster accepted by colleagues and

- faster knowledge transfer from employees to foreigners.

For successful onboarding of the foreigner in practice we can do the following (Employee onboarding processes: plans, best practices, flowcharts n.d.):

- at first we friendly accept the foreigner to the company and show him/her the company if we have not already done so,

- introduce him/her to colleagues and highlight his/her potential major successes and what its contribution to the company means,

- introduce him/her the internal rules (rules, regulations) that he/she must be familiar with,

- introduce him/her to a mentor who will regularly follow him/her during his/her probationary period,

- prepare a deployment plan for it and accurately inform it,

- introduce him/her to his/her post,

- we arrange with him/her any other formalities (contract signature, e-mail address, card for recording working hours, etc.),

- regularly monitor his progress (daily, weekly, monthly) and discuss the results with the foreigner,

- we are constantly available for help and additional questions (the first address for this is his/her mentor, then the head of the department, the director).

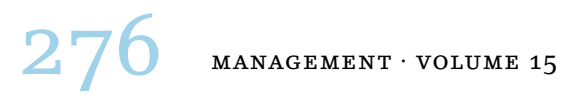




\section{Knowledge Transfer to a Foreigner}

When we hired a foreigner and brought him/her into the company, the knowledge transfer began for him/her. At the outset, he/she must become familiar with the various rules and regulations that apply to the company, the procedures and how it works. This is where the knowledge transfer that is most valuable to the organization begins.

The job description itself states what knowledge and to what extent the employee must have for the job. He brings his formal knowledge with him, which is often not the same, as in the case of workers from $\mathrm{BiH}$ and Serbia, as is required for his post. It also brings the informal, which in most cases is decisive when hiring foreigners. Regardless of the knowledge that an individual brings to the company, the way and the work process can be completely different from the previous ones that the foreigner has already done. In order for the latter to be able to perform his work well, efficiently and above all correctly, it is essential that the knowledge of his colleagues, which is necessary for his work, is imparted to him. In practice, this occurs as part of mentoring, as the mentor is the one who introduces the foreigner into the work. The mentor and the foreigner collaborate on a daily basis and knowledge transfer is ongoing, either through conversation or through various media (e.g. CDS on a CD, protocol of a leaflet procedure, etc.).

Nevertheless, knowledge transfer can be 'stuck' despite good onboarding and a good relationship between a foreigner and a mentor. Therefore, it is necessary for the associates to be trusted and have more teamwork and training. It is also recommended that the foreigner and other employees, when arriving at the company, alternate between jobs so that they get to know each other more closely. This allows all the articles in the chain to understand the workplace and realize that, for example, storekeepers need certain knowledge and skills to be able to perform their work qualitatively. Alternating also brings knowledge from a completely different field and it may appear as a solution to some of the problems in the processes of another department.

We should inform the foreigner at the beginning of the deployment that in the organization we do not own knowledge, but share it and promote socialization among our colleagues in order to transfer knowledge and good practices. An important task of the employer is to constantly motivate the foreigner to further his/her education and thus increase his/her own and organizational competitiveness.

Employment of foreigners in Slovenia, with an emphasis on for- 
eigners from $\mathrm{BiH}$ and Serbia, remains open in our labour market. In fact, forecasts indicate that many professions will be in short supply, which means that demand was higher than supply. This is especially true for manufacturing professions such as mechanical engineering, transport, catering, etc. Up to now, the majority of workers have been recruited from $\mathrm{BiH}$ and Serbia to perform work in the mentioned fields, as they are considered to have a large number of suitable candidates and are ready to accept the working conditions offered by Slovenian employers. Certainly contributing to the successful employment of a foreigner is the knowledge of how to find suitable candidates, all those involved in this procedure, and knowledge of the recruitment procedures of a foreigner from $\mathrm{BiH}$ and Serbia. With all of the above, the employer should be aware of the good onboarding and integration of the foreigner into the work environment, as well as the necessary activities for knowledge transfer.

\section{Research and Management Suggestions}

Our research, among other things, was intended to investigate and determine which method of on-the-job training employers most commonly use and to verify our hypothesis we have made analysis and interpreting the data obtained.

\section{METHODS AND CHARACTERISTICS OF THE SAMPLE}

We used quantitative research for verification purposes. The survey was conducted with the help of a survey questionnaire, which was created in the web application $1 \mathrm{KA}$. To interviewed companies we sent an e-mail to their publicly available e-mail addresses explaining the purpose of the survey and adding a link to access the survey website, specifically to the heads of human resources and heads of human resources management departments.

The sample or population was represented by Slovenian companies of different sizes and selected activities, which were published in the electronic format of TDS (Telephone Directory of Slovenia), while trying to follow the structure of entities in reality (company size). 5,000 companies from different industries were randomly selected. The survey was conducted between June 30 and July 9, 2019. $830(16.6 \%)$ respondents answered the survey and 339 (6.78\%) respondents filled it out completely.

The collected data were analysed using the spss software tool, and the results were presented using tables. Descriptive statistics were used to determine the characteristics and composition of the sample, and the hypothesis was tested using inferential statistics. First,

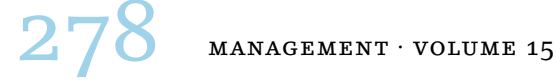


TABLE 1 Overview of Survey Completion Data with Respect to Completion of Survey Completion

\begin{tabular}{rrrrr}
\hline Completed & $\begin{array}{r}\text { Partially } \\
\text { completed }\end{array}$ & $\begin{array}{r}\text { Total } \\
\text { appropriate }\end{array}$ & $\begin{array}{r}\text { Total } \\
\text { inadequate }\end{array}$ & Total \\
\hline 284 & 55 & 339 & 491 & 830 \\
\hline
\end{tabular}

we used the calculation of $\chi^{2}$ for the variables tested and their distributions, but since the latter was not uniform, we used the largest percentage of the possible answers to test the hypothesis.

The limitations of the survey were, in the end, reflected in the respondents' perceived unresponsiveness and in the large number of incorrectly or incompletely filled surveys.

\section{BASIC ANALYSIS OF DATABASE VARIABLES}

First, we asked the respondents about the industry, size and age of the company, the number of employees and the region of the company's headquarters. A total of 339 questionnaires were completed (table 1).

182 (53.7\%) micro, 97 (28.6\%) small, 49 (14.5\%) medium-sized and $11(3.2 \%)$ large companies participated in the survey. In the sample structure, the proportion of large firms was larger than the structure in reality, but large firms had greater employment needs.

According to the industry $78(23 \%)$ companies come from construction, $62(18.3 \%)$ in motor trade, maintenance and repair of motor vehicles, $39(11.5 \%)$ in manufacturing, $35(10.3) \%)$ in the catering industry, $22(6.5 \%)$ in transport and storage, and 103 (30.4\%) in other industries.

According to the region from which the surveyed companies come, 119 companies were from central Slovenia (35.1\%), 44 from Gorenjska (13\%), 37 from Podravska (10.9\%), 35 from Savinjska (10.3\%), 23 from Goriška (6.8\%), 15 from the Coast and Karst (15\%), from Koroška and Notranjska each 13 companies (3.8\%), 12 from Posavje (3.5\%), 10 and 11 (2.9\% and 3.2\%) from Pomurje and Primorskonotranjska and from Zasavje 7 (2.1\%). The result obtained was expected, as the largest number of companies is registered in central Slovenia, and Zasavje region is a rather small area.

Our research hypotheses were:

н1 Existing employees welcome foreigners well or very well if the company cooperates in their integration into the work environment.

H2 Slovenian companies employ the most foreigners from $\mathrm{BiH}$ due 
TABLE 2 Employment of Foreigners in the Workplace, According to Employers

\begin{tabular}{lrrr}
\hline Answer & $(1)$ & $(2)$ & $(3)$ \\
\hline Well & 66 & 19.5 & 60.6 \\
Very well & 40 & 11.8 & 97.2 \\
Bad & 3 & 0.9 & 100 \\
\hline Total & 109 & 32.2 & \\
\hline
\end{tabular}

Notes Column headings are as follows: (1) frequency, (2) percentage, (3) cumulative percentage.

to the fact that Slovenian workers do not want to perform a certain job or demand a higher pay for the same job.

н3 Most companies face discrimination against the foreigner when they are hiring him.

H4 Too much administration is the most common problem in the process of arranging documentation for the employment of a foreigner.

\section{TESTING HYPOTHESES}

Our research hypothesis $\mathrm{H} 1$ was: Existing employees welcome foreigners well or very well if the company cooperates in their integration into the work environment.

In the questionnaire, we asked the respondents the question 'How is a foreigner usually accepted into the work environment by existing employees?' They were able to choose from the following: very good, good, bad and very bad. The question was answered again by all those who employ foreign labour, i.e. 109 (32.2\%) companies surveyed. As table 2 shows, as many as $97.2 \%$ of respondents or 106 companies chose positive answers, i.e. 'Very good' (40 companies or $36.7 \%$ of respondents) and 'good' (66 companies or $60.6 \%$ of respondents).

We examined the correlation between the selected variables, 'How a foreigner is usually accepted into the work environment by an existing employee' and 'Do you work with a foreigner to integrate him/her in the work environment' (Table 3). We find that the variables are positively correlated (Pearson's correlation coefficient is o.239). This means that the more opportunities and ways to help the stranger integrate into the work environment are offered by the employer, the easier it will be for them and, consequently, the foreigner will be better accepted by existing employees.

Integrating foreigners into the work environment and acceptance of them by existing employees is, as other authors note (Jerala, Pod- 
TABLE 3 Correlation between Inclusion of Foreigners in the Work Environment of the Company and Their Acceptance by Existing Employees

\begin{tabular}{llrr}
\hline Question & Item & $(1)$ & $(2)$ \\
\hline (1) Do you work with a foreigner & Pearson's correlation & 1 & 0.239 \\
to integrate him/her into your & Significance (double test) & & 0.012 \\
work environment? & Sample & 109 & 109 \\
\hline (2) How is a foreigner usually ac- & Pearson's correlation & 0.239 & 1 \\
cepted into the work environ- & Significance (double test) & 0.012 & \\
ment by existing employees? & Sample & 109 & 109 \\
\hline
\end{tabular}

TABLE 4 Employment Frequency in Selected Countries by Employer Choice

\begin{tabular}{lrrr}
\hline Country & $(1)$ & $(2)$ & $(3)$ \\
\hline Bosnia and Herzegovina & 109 & 2.20 & 2.300 \\
Serbia & 109 & 5.57 & 2.891 \\
Croatia & 109 & 6.44 & 2.584 \\
Hungary & 109 & 7.53 & 1.608 \\
Italy & 109 & 7.63 & 1.482 \\
Austria & 109 & 7.64 & 1.424 \\
\hline
\end{tabular}

Notes Column headings are as follows: (1) sample, (2) average, (3) standard deviation.

goršek and Toš 2016, 11-5; Ferk and Boštjančič 2015, 3), extremely important, as it also depends on knowledge transfer and skills between them. As we also find in our research, the acceptance of a foreigner into the work environment and the support of the company in its integration into the work environment are strongly interconnected, which is why we confirmed $\mathrm{H} 1$.

Hypothesis H2 was: Slovenian companies employ the most foreigners from $\mathrm{BiH}$ due to the fact that Slovenian workers do not want to perform a certain job or demand a higher pay for the same job.

In conducting the survey, respondents were required to select the country in a way by entering the number 1 in the country from which they employ the most foreigners, 2 in the next country from which they employ the most foreigners, and thus to a score of 6 . It follows that the lower average score means that in Slovenia are employed the most foreigners from that country.

Below, we also needed to check the correlation of the variables of the two survey questions, namely 'Why did you decide to hire a foreigner: because Slovenian workers do not want to perform a particular job or require higher pay for the same work' and 'From which countries do you hire the most foreigners: BiH.' We found that the relationship was negative (Pearson's correlation coefficient was -0.046) 
TABLE 5 Correlation between the Demand of Slovenian Workers for higher Pay and the State of $\mathrm{BiH}$

\begin{tabular}{llrr}
\hline Question & Item & $(1)$ & $(2)$ \\
\hline (1) Slovenian workers do not want & Pearson's correlation & 1 & -0.046 \\
to perform a certain job or de- & Significance (double test) & & 0.633 \\
mand a higher pay & Sample & 109 & 109 \\
\hline (2) Bosnia and Herzegovina & Pearson's correlation & -0.046 & 1 \\
& Significance (double test) & 0.633 & \\
& Sample & 109 & 109 \\
\hline
\end{tabular}

TABle 6 How Many Companies Are Experiencing Difficulties in Hiring a Foreigner

\begin{tabular}{lrrr}
\hline Answer & $(1)$ & $(2)$ & $(3)$ \\
\hline No & 77 & 70.6 & 70.6 \\
Yes & 32 & 29.4 & 100.0 \\
\hline Total & 109 & 100.0 & \\
\hline
\end{tabular}

Notes Column headings are as follows: (1) frequency, (2) percentage, (3) cumulative percentage.

and that the variables were not interdependent (table 5). The research shows that employers mostly choose to hire foreigners from $\mathrm{BiH}$, but not because Slovenian workers would not want to do a certain job or demand higher pay, so we only partially confirmed н2.

The н 3 hypothesis was: Most companies face discrimination against foreigner when they are hiring him.

First, we have done an analysis of how many companies are facing difficulties when hiring a foreigner while joining a company. As table 6 shows, just under one third of all surveyed companies (32 and $29.4 \%$ ) employing foreigners are facing difficulties.

Then we were able to test the hypothesis in terms of problems and their frequency. The respondents had a written set of problems and one vacancy where they could write a problem themselves that the questionnaire did not offer. For each of the problems they had to choose a value from 1 to 5 , with 1 being never and 5 being very common. As table 7 shows, companies most often encounter foreigners' unwillingness to adapt to the new environment (2.91) and communication problems (2.69) when employing a foreigner. According to the results of the conducted survey, discrimination of foreigners by existing employees is in third place (1.66).

The impact on the acceptance of a foreigner and discrimination by existing employees has already been investigated by other authors (Vrečer et al. 2008, 7; Polajnar et al. 2001, 7), and they conclude that 
TABLE 7 Frequency of Selected Employers' Problems

\begin{tabular}{|c|c|c|c|c|c|c|}
\hline Problem & (1) & (2) & (3) & (4) & (5) & (6) \\
\hline $\begin{array}{l}\text { The foreigner's unwilling- } \\
\text { ness to adapt to the new } \\
\text { environment }\end{array}$ & 11.558 & 31 & 0.000 & 2.906 & 2.39 & $3 \cdot 4^{2}$ \\
\hline Communication problems & 9.412 & 31 & 0.000 & 2.688 & 2.11 & 3.27 \\
\hline $\begin{array}{l}\text { Discrimination against for- } \\
\text { eigner by co-workers (in- } \\
\text { cluding managers) }\end{array}$ & 8.551 & 31 & 0.000 & 1.656 & 1.26 & 2.05 \\
\hline $\begin{array}{l}\text { Harassment against for- } \\
\text { eigner by co-workers (in- } \\
\text { cluding managers) }\end{array}$ & 9.680 & 31 & 0.000 & 1.438 & 1.13 & 1.74 \\
\hline Other & 4.000 & 8 & 0.004 & 1.333 & .56 & 2.10 \\
\hline \multicolumn{7}{|c|}{$\begin{array}{l}\text { NOTEs Column headings are as follows: (1) } t \text {-distribution, (2) freedom rates, (3) sig- } \\
\text { nificance (double test), (4) mean difference, (5) lower } 95 \% \text { confidence interval of dif- } \\
\text { ference, (6) upper } 95 \% \text { confidence interval of difference. }\end{array}$} \\
\hline \multicolumn{7}{|c|}{ TABLE 8 Overview of How Many Companies Employ Foreigners } \\
\hline Answer & & & & (1) & $(2)$ & (3) \\
\hline No & & & & 175 & 51.6 & 61.6 \\
\hline Yes & & & & 109 & 32.2 & 100.0 \\
\hline Total & & & & 284 & 83.8 & \\
\hline Interrupted & & & & 55 & 16.2 & \\
\hline Grand total & & & & 339 & 100.0 & \\
\hline
\end{tabular}

NOTES Column headings are as follows: (1) frequency, (2) percentage, (3) cumulative percentage.

this arises from language barriers, unwillingness to adapt to the new environment, as well as in terms of political, psychological and sociocultural barriers. In our study, however, we also find that a foreigner's unwillingness to adapt to the new environment is the most common cause of employer's difficulties in integrating foreigner into the work environment. Due to the above and due to the results н3 is rejected.

Hypothesis H4 was: Too much administration is the most common problem in the process of arranging documentation for the employment of a foreigner.

When checking H4, we first checked how many surveyed and participating companies employ foreigners at all. As can be seen from table 8, 109 companies out of 284, who have completely filled out the survey, are employing foreigners. This represents a $32.2 \%$ share of our sample.

Then we checked how many were experiencing difficulties in hiring foreigners. To the question from the survey 'Do you have any 
table 9 Overview of How Many Companies Are Facing Difficulties in the Process of Arranging Documentation for the Employment of a Foreigner

\begin{tabular}{lrrr}
\hline Answer & $(1)$ & $(2)$ & $(3)$ \\
\hline Yes & 59 & 17.4 & 54.1 \\
No & 50 & 14.7 & 100.0 \\
\hline Total & 109 & 32.2 & \\
\hline
\end{tabular}

Notes Column headings are as follows: (1) frequency, (2) percentage, (3) cumulative percentage.

TABLE 10 Frequency of Difficulties in the Process of Arranging Documentation for the Employment of a Foreigner from the Perspective of the Employer

\begin{tabular}{lrrrrrr}
\hline Problem & $(1)$ & $(2)$ & $(3)$ & $(4)$ & $(5)$ & $(6)$ \\
\hline Too much administration & 49.723 & 58 & 0.000 & 4.695 & 4.51 & 4.88 \\
Too long legal deadlines & 47.722 & 58 & 0.000 & 4.678 & 4.48 & 4.87 \\
Unknowing the process & 12.400 & 58 & 0.000 & 2.356 & 1.98 & 2.74 \\
Foreigner not participating & 11.988 & 58 & 0.000 & 1.542 & 1.28 & 1.80 \\
Other & 5.286 & 14 & 0.000 & 2.467 & 1.47 & 3.47 \\
\hline
\end{tabular}

Notes Column headings are as follows: (1) $t$-distribution, (2) freedom rates, (3) significance (double test), (4) mean difference, (5) lower 95\% confidence interval of difference, (6) upper $95 \%$ confidence interval of difference.

problems with the process of arranging the documentation for employment of a foreigner?,' 59 (54.1\%) answered that they are experiencing difficulties.

After this, we then checked for the employment of a foreigner which problems are most common among the companies that are experiencing difficulties in the process of arranging documentation. Again, on this question, the respondents chose the value of the listed problems at their discretion with 5-point Likert scale, from 1 (never) to 5 (very common occurrence in practice). Employers emphasized 'too much administration' (4.69) and 'too long legal deadlines' (4.68) as the most common problem. A $t$-test was used to test the hypothesis, and the results are presented in table 10.

The average score of 4.69 points to the fact that companies face serious difficulties in managing the documentation for employment of foreigners. In practice, this may mean, in particular, that extensive and numerical documentation is required, which companies must obtain before employing a foreigner. In addition, according to the employers, the legal deadlines are too long, due to the fact that they are in a hurry to hire a suitable worker. According to the research findings, $\mathrm{H} 4$ can be confirmed.

We confirmed the $\mathrm{H} 1$ hypothesis as respondents were unanimous 
that more options and ways to help a foreigner than an employer offers, make it easier to integrate him/her into the work environment and, consequently, be better accepted by existing employees. Employers are also increasingly aware of the need to respect and understand the employees. Personnel management has been transformed into human resources management, where each individual has his/her own value and his/her best possible integration into the work environment is very important and has a great impact on the quality of work of all. The awareness of the importance of good integration of the foreigner and assistance to the foreigner coincides with these findings. Improvements in the integration of foreigners into the work environment are seen primarily in the attitude of managers and co-workers towards the foreigner. A foreigner who came from another cultural background will need more time to adjust. Therefore, it is important that he/she be assisted and accepted in as many ways as possible: socializing with him/her even outside working hours, assistance in understanding the Slovenian language, assistance in legal matters to regulate his status, providing accommodation, mentoring, etc.

Based on the results, we found that employers employ the largest number of foreigners from $\mathrm{BiH}$, but for reasons other than those we assumed in the hypothesis set out, we therefore only partially confirm the $\mathrm{H} 2$ hypothesis. The result is interesting and unexpected, as certain occupational profiles in Slovenia are lacking and there are still some suitable workers for some jobs for which they do not apply. From experience, we can note that Slovenian workers do not decide for employment with Slovenian employers because they receive a higher pay for the same job in Austria or Germany. From this we could also conclude that the employers' answers were not completely honest, or. we should conduct a specific survey related to the offered working conditions and the remuneration for the work performed. This data would then give us a more complete picture of the paradox that emerges when there are suitable workers in the domestic market, while at the same time companies are forced to employ foreigners in these jobs.

Regardless of this, the relevant candidates, to whom the working conditions of Slovenian employers are acceptable, are large in $\mathrm{BiH}$ and Serbia, but at the same time have extensive experience and necessary knowledge. The suggestions for improvement are similar to those for H1. It is essential to change the attitude of the company towards certain professions and to improve both working conditions and remuneration for the work done in those professions. Only in 
this way we will avoid the growing shortage of suitable candidates in selected professions.

According to the results of the survey, we rejected the H3 hypothesis because the survey showed that when hiring a foreigner, companies most often encounter a foreigner's unwillingness to adapt to a new environment rather than discrimination by co-workers. We are sceptical of the result of this hypothesis, because in our experience discrimination against a foreigner is the one that causes the most problems for employers when hiring. Employers identified communication problems as the most common problem when hiring a foreigner. By the lack of personnel is most prominent especially in technical profiles, where the Slovenian language is not the most important prerequisite for the proper performance of the work, and the fact that the Slovenians are good at or understand or speak the languages of our former common state of Yugoslavia (most foreigners are employed right from $\mathrm{BiH}$ and Serbia), communication problems do not seem to us to be the honest answer. Here, too, we relate to the comment that we wrote about the result of the research in the comment for hypothesis H2. Regardless of the result of the hypothesis, we think that it is still too often the case that a foreigner is not properly accepted by his co-workers due to his nationality in the work environment, which in turn leads to job dissatisfaction, conflicts, demotivation ... It is very important what kind of the leadership companies give, and that the they clearly state what is strictly prohibited (discrimination, etc.). Discrimination should not be tolerated, but whoever practices it must be held accountable. It may be worth pointing out here that in cases of employment of foreigners, we are aware of the fact that discrimination may no longer be present, because new employees from foreign countries come to a work environment where someone from their home environment may already be employed. The latter represent their stronghold and guarantee greater acceptance in the work environment and less discrimination. In the context of the communication problems, we suggest that employers offer foreigners a free Slovene language course and mentoring by a person who speaks his/her language.

We confirmed the hypothesis $\mathrm{H}_{4}$, because employers were exposed to too much administration and too long legal deadlines as the most common problem in the process of arranging documentation for a foreigner's employment. We expected the confirmation of the hypothesis at the beginning of our research. One of authors of this paper works in the field of employment of foreigners and from her own experiences there is too much administration in the process 
of hiring a foreign person. We agree with the fact that documentation must be transparent, but in the age of information technology, we can use it in a better way. Since, in line with the theoretical part of the research, the state itself is aware of the need to shorten and simplify administrative procedures, it is first necessary to start amending the legislation. The procedures have been simplified in recent years, but the employment of foreigners is increasing and the need for change is increasing. It can optimize the current method of data entry by computerizing work processes, which mean faster process execution and consequently lower costs.

\section{Conclusion and Proposals for Management}

The focus of our research was to identify and explore the field of employment of foreigners in Slovenia, with an emphasis on the employment of foreigners from $\mathrm{BiH}$ and Serbia. The fact is that we are currently in a period where the suitable candidates are hard to find. Especially when it comes to jobs that require a profession that is lacking in Slovenia. The decisions of schools in the last century, when they gradually stopped the education of certain professions due to the lack of demonstrated interest of students, today show consequences. In the labour market, there is a severe shortage of car repairers, processors, construction workers, catering workers, truck drivers, and workers in storage and so on. Although employers are trying to attract domestic workers, working conditions are still considered difficult for these professions and wages for our situation too low.

As a result, more and more employers are choosing to hire a foreigner. The payment offered by the Nordic countries for the abovementioned professions, which is often the central criterion of an individual for applying for a job, cannot be overcome in Slovenia. Much better living standards and significantly better pay can be offered to workers from the countries of the former Yugoslavia. Since there are many desired profile workers there, hiring a foreigner from $\mathrm{BiH}$ or Serbia is a completely logical decision. Employment of foreign workers has been on the rise for a long time, so Slovenia has decided to ease the procedures for their employment. Although these are still not optimal, they are much faster and simpler. Regardless, employers are still very often faced with various obstacles and difficulties in their implementation.

Experts believe that if employment of foreigners continues until at least 2020/2021, such as forecasts for economic growth, our country will have to take even more steps to obtain the necessary labour 